\title{
Anti-Hyperglycemic Activity and Phytochemical Studies of Aerva Javanica
}

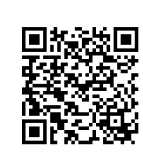

\author{
Mohammad Kamil*, F Ahmad and El T Abdalla \\ Department of Health, UAE
}

Submission: March 09, 2021; Published: April 16, 2021

*Corresponding author: Mohammad Kamil, TCAM Research, Zayed Complex for Herbal Research \& Traditional Medicine DHLME, Department of Health, Abu Dhabi, UAE

Keywords: $\beta$-Sitosterol; $\alpha$-amyrin; Palmitic; Stearic; Linoleic; Myristic; Palmitoleic; Oleic acids; $\beta$-sitosterolglucoside; Oleanolic acid; Kaempferol-

3-galactoside; Kaempferol-3-rhamnogalactosid; Hentriacontane; Nonacosane; Nonacosanol; Tritriacontane; Tetratriacontane; Flavanone

\section{Description}

Perennial straggly bush, frequently woody, growing in erect clumps, $0.3-1.5 \mathrm{~m}$, branched from about the base with simple stems or the stems with long, ascending, sometimes intricate branches. Stem and branches terete, striate, \pm densely whitish- or yellowish- tomentose or pan nose, when dense the indumentums often appearing tufted. Leaves alternate, extremely variable in size and form, from narrowly linear to sub orbicular, \pm densely whitish- or yellowish tomentose but usually more thinly so and greener on the upper surface; margins plane or involute (when strongly so the leaves frequently \pm falcate-recurved), sessile or with a short and indistinct petiole or the latter rarely to c. $2 \mathrm{~cm}$ in robust plants (Figures $1 \& 2$ ).

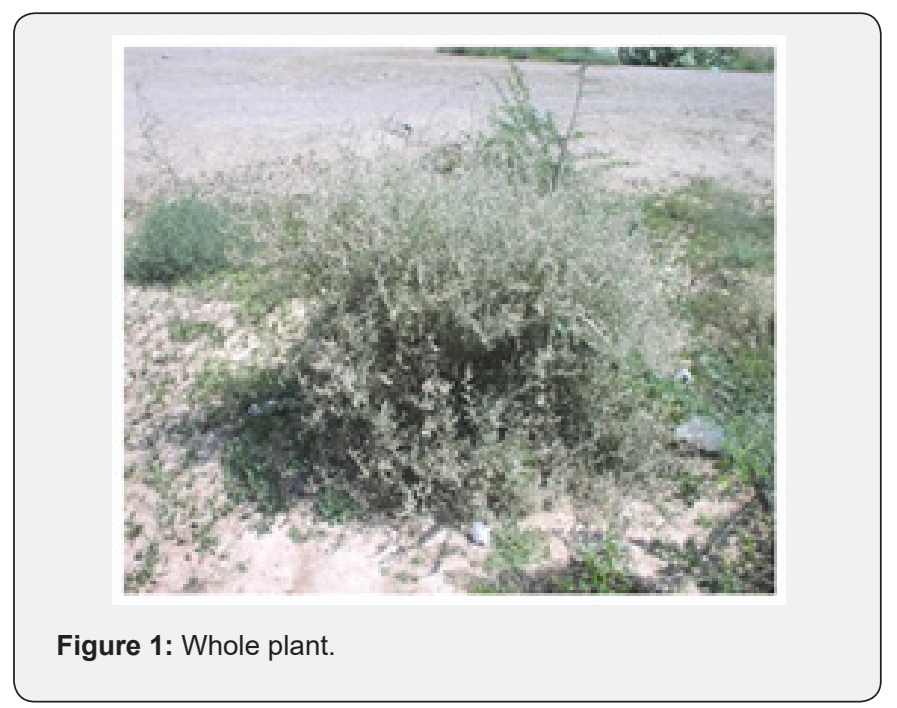

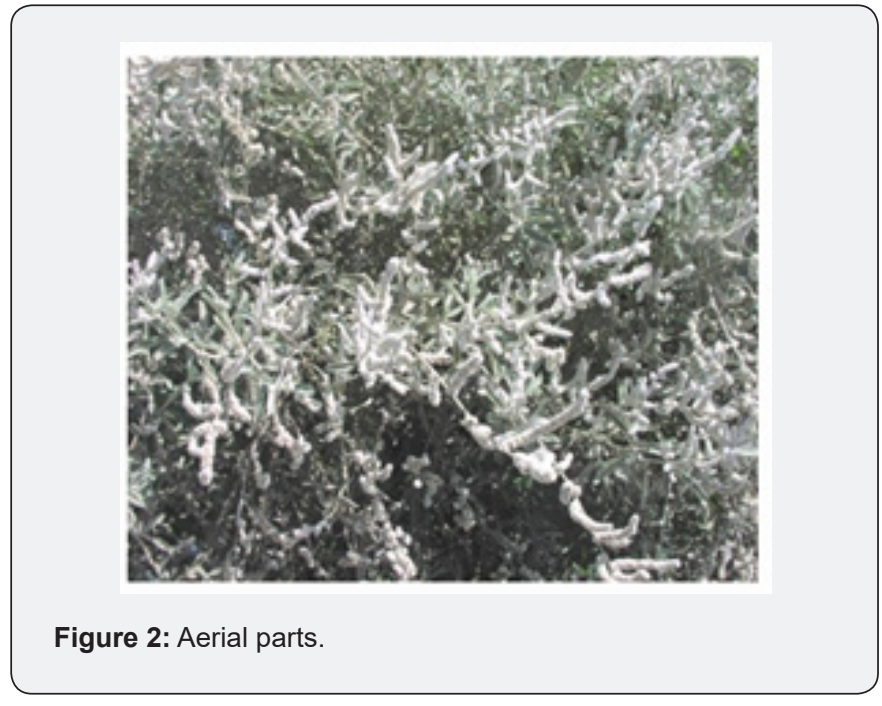

Flowers dioecious. Spikes sessile, cylindrical, dense and stout (up to c. $10 \times 1 \mathrm{~cm}$.), to slender and interrupted with lateral globose clusters of flowers and with some spikes apparently pedunculate by branch reduction; male plants always have more slender spikes (but plants with slender spikes may not be male); upper part of stem and branches leafless, the upper spikes thus forming terminal panicles; bracts $0.75-2.25 \mathrm{~mm}$, broadly deltoidovate, hyaline, acute or obtuse with the obscure midrib ceasing below the apex, densely lanate throughout or only about the base or apex, persistent; bracteoles similar, also persistent. Female flowers with outer 2 tepals $2-3 \mathrm{~mm}$, oblong-obovate to obovatespathulate, lanate, acute to obtuse or apiculate at the tip, the yellowish midrib ceasing well below the apex; inner 3 slightly 
shorter, elliptic-oblong, \pm densely lanate, acute, with a narrow green vitta along the midrib, which extends for about two-thirds the length of each tepal; style slender, distinct, with the two filiform, flexuose stigmas at least equaling it in length; filaments reduced, anthers absent. Male flowers smaller, the outer tepals $1.5-2.25 \mathrm{~mm}$, ovate; filaments delicate, the anthers about equaling the perianth; ovary small, style very short, stigma rudimentary. Capsule 1-1. $5 \mathrm{~mm}$, rotund, compressed. Seed 0.9-1.25 mm, round, slightly compressed, brown, or black, shining, and smooth or very faintly reticulate [1-5].

\section{Habitat and Distribution}

Its native distribution ranges from northern Africa to the southwestern regions of Asia, and throughout Arabia and in the drier parts of the tropics and subtropics. Grows in disturbed and irrigated places. Common by roadsides and in stony and gravelly wadis and hillslopes. The plant is widespread in the U.A.E, especially in the Northern Emirate, where it is found on roadsides, disturbed sites; silt in rocky wadis and on alluvial plains.

\section{Part used}

Whole plant and aerial parts

\section{Traditional and medicinal uses}

The plant is used by traditional medicine practitioners for the treatment of kidney stones, inflammation, skin infection, toothache, headache, and abdominal worms. The flowers are used for the treatment of wounds by mixing with water to form a paste, which is used as wound dressing and to stop bleeding. Fumigant of the whole plant is used as an aphrodisiac $[3,4]$.

\section{Pharmacognosy and Phytochemistry}

\section{Plant material studied}

Dried leaf with occasional floral spikes.

\section{General appearance}

The leaf is light grayish green in color in the upper surface, while the lower surface has a silvery gray color and a woolly touch. It is brittle and when dried, it curls inwards, exposing the lower epidermis outwards. Leaves vary in length (15-40 mm) and they are about $5 \mathrm{~mm}$ broad. They are usually mixed with spikes of white flowers having a very light weight.

\section{Microscopic characteristics}

The leaf is unilateral, where the upper epidermis only (not the lower epidermis) is underlain by a layer of palisade tissues. Regarding the surface view, the upper epidermal cells are shown to have sinuous (wavy) cell walls. The epidermis bears many characteristic covering trichomes - including peculiar branching in trichomes as the major ones - in addition to occasional curved simple covering trichomes, each with about three basal cells and a tapering end. The palisade cells are oblong with thin cell walls and wide lumens, and some of them contain calcium oxalate prisms. The spongy mesophyll cells are polygonal in shape and a part of them contains a single large cluster crystals of calcium oxalate while those surrounding the vascular tissues are quite characteristic, as they appear as a circle of polygonal cells with thick cell walls. The lower epidermis consists of relatively small cells, but it bears numerous different covering trichomes, especially the branched ones. Stomata are found on both epidermises and they are oval and anomocytic.

\section{Plant material studied}

Dried stem and branches

\section{General appearance}

The stem and branches have a light grayish green color; they are cylindrical in outline and have a slightly coarse touch. The branches are slender and are 1-2 $\mathrm{mm}$ in diameter. They are brittle and when cut, they show dark-colored internal tissues. A cross section of the stem shows its cylindrical outline. The epidermis consists of anticlinal oblong cells, which bear many peculiar, branched covering trichomes as those borne on the leaf, in addition to a few simple conical ones. The epidermis is underlain by a few layers of collapsed parenchyma cells with thick cell walls and some of these contain brown pigments. The cortex is composed of parenchyma cells, which are nearly rounded. The outermost cortical layers enclose a layer of interrupted groups of lignified fibers, where each fiber is divided into compartments with thick walls and wide lumens. The cortical endodermis is not well defined. On the other hand, the vascular tissues are heavily lignified, and they include large vessels with wide lumens. The pith occupies a wide central zone, and it consists of large characteristic polygonal cells with thick pitted (perforated) cell walls.

\section{Powdered plant material}

The materials consist of the pounded aerial parts. It is a light, hairy, raw-cotton-like white powder with a yellowish tint. It has an odor reminiscent of dried straw and an almost flat taste but with a very slight bitterness. Microscopically, the powder shows numerous long intermingling covering trichomes with several short sharp side protrusions together with stellate trichomes. Fragments of the green leaves are very rich in translucent rosettes of calcium oxalate, which are almost circular in outline. Calyx or corolla parts have characteristic long narrow cells with conspicuous cell walls (Figure 3).

\section{Chemical constituents}

The presence of steroids [6], triterpenoids [7], carbohydrates [8], flavonoids [9], and saponin content [10] have been reported. Flavonol: Isorhamnetin-3-0- $\beta-\left[4^{\prime \prime \prime}\right.$-p-coumaroyl- $\alpha$ rhamnosyl $(1 \rightarrow 6)$ galactoside] (Nabiel, 1990). Isorhamnetin3-0-[4-o-p-coumaroyl- $\alpha$-L- $\quad$ rhamnopyranosyl-(1 $\rightarrow 6-\beta-D-$ galactopyranoside] [11]. Coumarins, sterols, triterpens [12]. The leaves contain hentriacontane, nonacosane, nonacosanol, 


\section{Current Research in Diabetes \& Obesity Journal}

tritriacontane, tetratriacontane, $\beta$-sitosterol (and its glucoside) and oleanolic acid, several glycosides of kaempferol and alkaloids (Ghazanfar, 1994). $\beta$ - Sitosterol, $\alpha$-amyrin, palmitic, stearic, linoleic, myristic, palmitoleic, oleic acids, $\beta$ - sitosterolglucoside and oleanolic acid; kaempferol-3-galactoside and kaempferol3-rhamnogalactosid; hentriacontane, nonacosane, nonacosanol, tritriacontane, tetratriacontane, Flavanone (aervanone) and kaempferol-3-0- $\beta$-[4"' - p-coumaroyl- $\alpha$-rhamnosyl $(1 \rightarrow 6)$ galactoside] [12-14]. Flavanone: (Persinol) and flavanone glucosides: (persinosides A and B) [15]. Coumarono chromone analogue: Aervins A, B, C, and D [16].
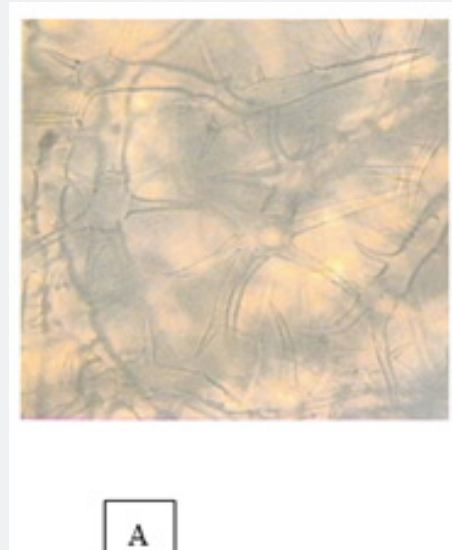

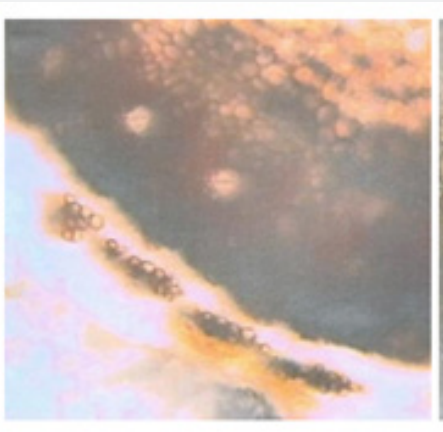

B

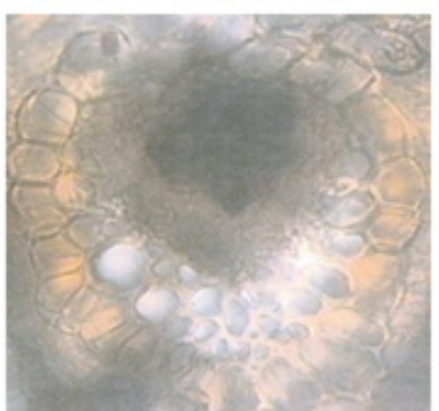

$\mathrm{C}$

Figure 3: A) TS of the leaf showing the upper epidermis with borne covering trichomes, palisade layer, and the characteristic polygonal cells that form a circle around the vascular tissues besides a spongy mesophyll cell that contains a large cluster crystal of calcium oxalate. B) TS of stem showing the heavily lignified vascular tissues including few large xylem tracheid's and many vessels (dark violet, red); also shown is a group of parenchymatous cells with thick pitted cell walls (light pink in color). C) A layer of fibers at the periphery separated from both epidermis and vascular tissues by a layer of parenchyma cells. The vascular tissues are heavily lignified. Circular lacunas are also observed within the vascular tissues (stem).

The following chemical studies have been carried out $[17,18]$ on the aerial part of the plant Aerva javanica (ZCHRTM unpublished work)

\section{Physicochemical constants (\%)}

Loss of weight on drying at $105^{\circ} \mathrm{C}: 8.10$

Absolute alcohol solubility: 4.00

Water solubility: 16.40

\section{Successive extractives (\%)}

Petroleum ether $(60-800)^{0} \mathrm{C}: 1.50$

Chloroform: 1.40

Table 1: Elemental Analyses.

\begin{tabular}{|c|c|c|c|c|c|}
\hline \multicolumn{5}{|c|}{ Ash Values (British Herbal Pharmacopeia- Reference) } \\
\hline \multicolumn{5}{|c|}{ Assay and Identification of Elements (AOAC International- Reference) } \\
\hline Apparatus & \multicolumn{5}{|c|}{ (AA-6800 Shimadzu-Flame method) } \\
\hline Element & Std.conc. $\mu \mathrm{g} / \mathrm{ml}(\mathrm{pp} \mathrm{m})$ & Sample conc. $\mathrm{mg} / \mathrm{ml}$ & Sample's absorbance & Actual conc.mg/ml & $\begin{array}{c}\text { Actual conc. } \\
(\%)\end{array}$ \\
\hline $\mathrm{Cr}$ & $1,2,4$ & 39.992 & 0.0018 & 0.00666 & 0.000666 \\
\hline $\mathrm{Zn}$ & $0.5,1,2$ & 39.992 & 0.2735 & 0.036605 & 0.00366 \\
\hline $\mathrm{Cu}$ & $0.5,1,2$ & 39.992 & 0.0542 & 0.018259 & 0.001826 \\
\hline $\mathrm{Fe}$ & $1,2,4$ & 39.992 & 0.5998 & 0.756491 & 0.075649 \\
\hline
\end{tabular}

Absolute alcohol: 7.50

\section{pH Values (aqueous solution)}

$\mathrm{pH}$ of $1 \%$ solution: 6.716

$\mathrm{pH}$ of $10 \%$ solution: 6.419

\section{Ash values (\%)}

Total ash: 11.50--13.35

Water soluble ash: 4.80

Acid insoluble ash (10\% $\mathrm{HCl}): 0.62-1.10$ (Tables 1 \& 2) (Figures 4-6). 


\section{Current Research in Diabetes \& Obesity Journal}

\begin{tabular}{|c|c|c|c|c|c|}
\hline $\mathrm{K}$ & $1,2,4$ & 39.992 & 2.0196 & 0.645782 & 0.064378 \\
\hline $\mathrm{Pb}$ & $1,2,4$ & 39.992 & 0 & 0 & 0 \\
\hline $\mathrm{Cd}$ & $0.25,0.5,1$ & 39.992 & 0 & 0 & 0 \\
\hline
\end{tabular}

$1 \mathrm{ppm}$ conc. $=1 \mu \mathrm{g} / \mathrm{ml} ;$ Actual conc. $(\%)=$ Actual conc. $(\mathrm{ppm}) \times 0.0001[1 \mathrm{ppm}=0.0001 \%]$

Table 2: UV spectral studies.

\begin{tabular}{|c|c|c|c|c|}
\hline $\begin{array}{c}\text { Sample conc. }(\mathrm{mg} / \\
\mathrm{ml})\end{array}$ & Solvent & $\lambda_{\max }(\mathrm{nm})$ & $\lambda_{\min }(\mathbf{n m})$ & $\operatorname{Abs} .\left(\lambda_{\max }-\lambda_{\min }\right)$ \\
\hline 0.92 & Intestinal Fluid simulated without pancreatic $\mathrm{pH}=7.5 \pm 0.1$ & 271 & 240 & 0.684 \\
\hline
\end{tabular}

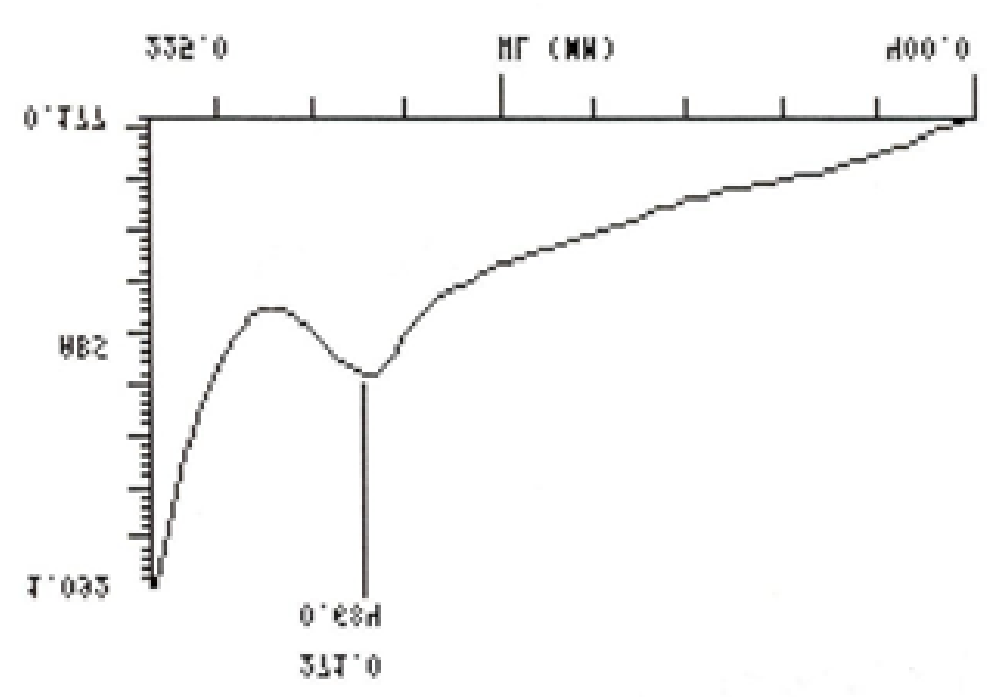

Figure 4: Intestinal Fluid simulated without pancreatic $\mathrm{pH}=7.5 \pm 0.1$.

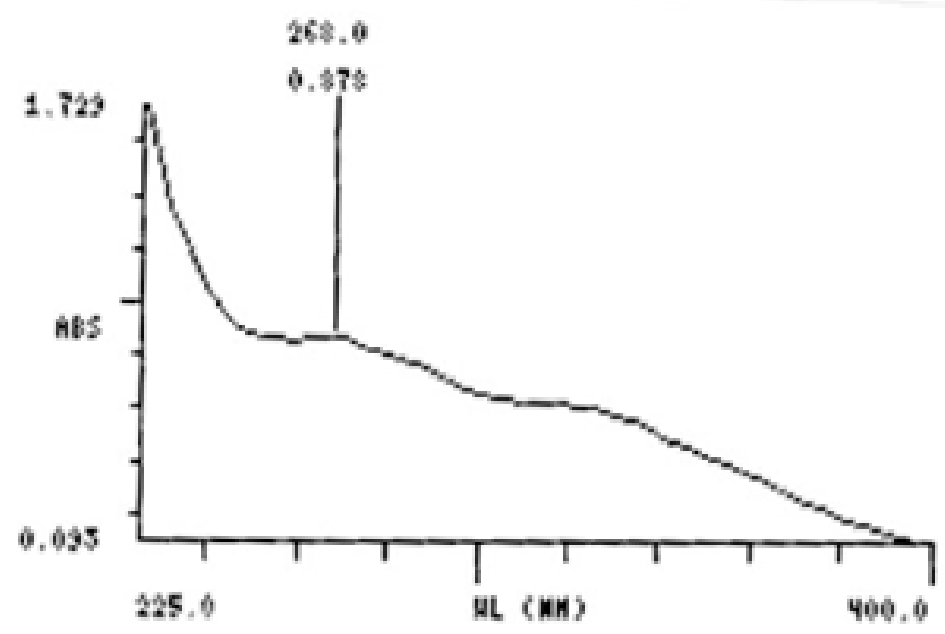

Figure 5: Gastric Fluid simulated without pepsin $\mathrm{pH}=1.2 \pm 0.1$. 


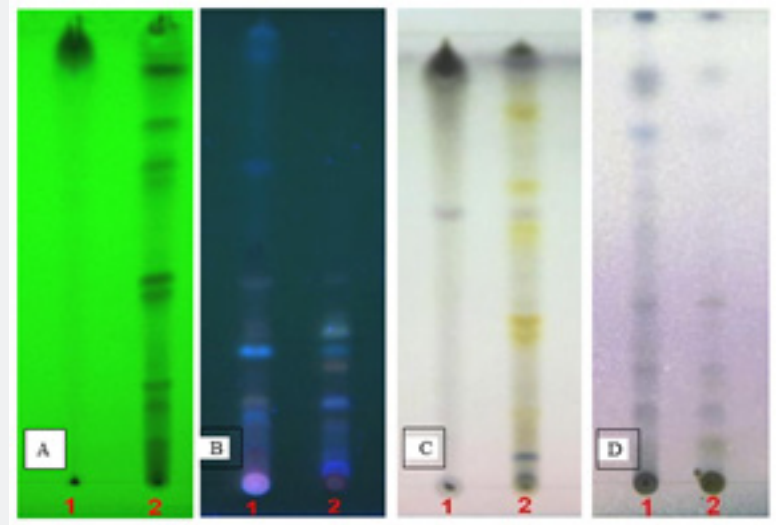

Figure 6: Thin layer chromatography (TLC) [18].

TLC fingerprint of Pet. ether 60-800 extract (track 1) and $\mathrm{MeOH}$ extract (track 2)

Mobile phase Figure D: Toluene, ethyl formate, formic acid (54:1); Figure B: Toluene, ethyl acetate (93:7); Figures A \& C: Ethyl acetate, methanol, water (100:13.5:10).

Detection Figure A: UV 254nm; Figure B: UV $366 \mathrm{~nm}$

Derivatization Figures C \& D: Vanillin-Sulphuric acid -vis.

\section{Pharmacological and toxicological studies: $(70 \%$} ethanol extract)

Methanolic extract of Aerva javanica leaves for C.N.S. depressant activity [20]. The plant has also been reported to have analgesic and anti-inflammatory activity [21]. Administration of the plant extract of the leaves were shown in different doses and in alloxan treated mice $(70 \mathrm{mg} / \mathrm{kg}$, i.e.) showed antihyperglycemic activity [22].

Aerva javanica has been reported to show significant antihyperglycaemic activity, justifying its use in the traditional system of medicine [22]. Aerva javanica is reported to inhibit the spontaneous activity in guinea-pig colon and rabbit jejunum, antihistaminic and antinicotinic activities on guinea-pig ileum [23]. It has been reported(betabisobolol) as a sedative and carminative. The leaves are used in early stage of diarrhea and dysentery [24]. Fifteen biological trace elements essential to plants, humans, and animals (silver, gold, cobalt, copper, chromium, nickel, lead, iron, magnesium, manganese, potassium, sodium, strontium, zinc, and calcium) were estimated and analyzed including Aerva javanica, which has been given uses as therapeutic agents for humans and in the treatment of mineral deficiency in animals [25]. The pharmacological and safety evaluation studies were carried out on the plant extract of Aerva javanica [26-31] as shown in Table 3 and Figures 7 \& 8.

Table 3: pharmacological and safety evaluation studies were carried out on the plant extract of Aerva javanica [25-31].

\begin{tabular}{|c|c|c|c|c|}
\hline \multirow{2}{*}{ Activity } & \multicolumn{4}{|c|}{ Results } \\
\hline & Strong & Moderate & Mild & Negative \\
\hline Antidiabetic & $\sqrt{ }$ & & & \\
\hline Analgesic & & & $\sqrt{ }$ & \\
\hline Antidepressant & & & & $\sqrt{ }$ \\
\hline Anti-gastric ulcer activity & $\sqrt{ }$ & & & \\
\hline Anticonvulsant & & & & $\sqrt{ }$ \\
\hline Effect on rabbit jejunum & & $\sqrt{ }$ & & \\
\hline Effect on rat fundus & & $\sqrt{ }$ & & \\
\hline Effect on guinea pig ileum & & $\sqrt{ }$ & & \\
\hline Effect on right rat atria & & $\sqrt{ }$ & & \\
\hline Antithrombotic effect & $\sqrt{ }$ & & & \\
\hline Diuretic effect & & & & $\sqrt{ }$ \\
\hline Studies on biochemical parameters & & & $\sqrt{ }$ & \\
\hline
\end{tabular}




\section{Current Research in Diabetes \& Obesity Journal}

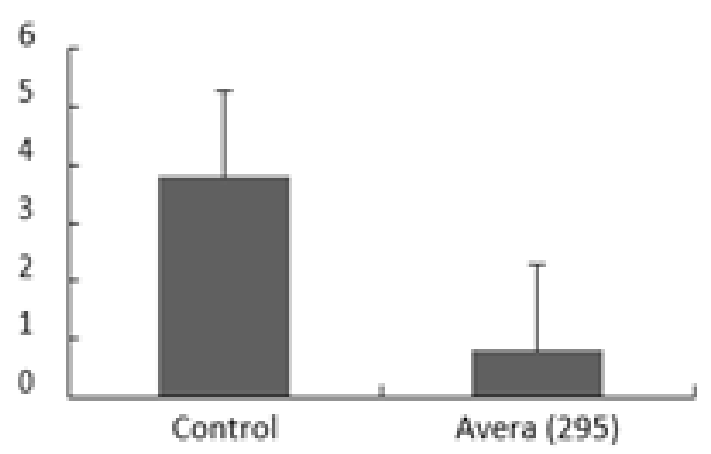

Figure 7: Effect of Aerva javanica $70 \%$ ethanol extract on gactric ulcer.

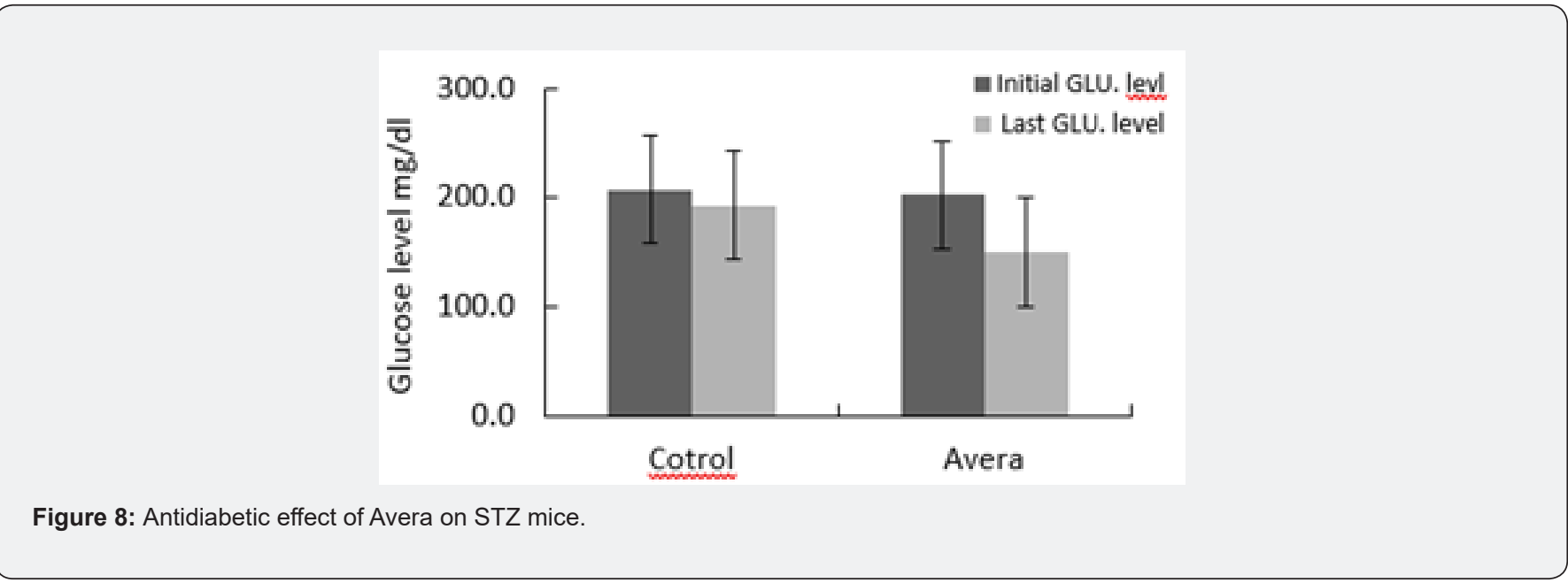

\section{Summary of the Results}

The present study shows that the oral administration of plant extract possesses potent anti-hyperglycemic activity; mild analgesic activity and mild antidepressant activity were also shown. The plant drug, at the dose of $1 \mathrm{~g} / \mathrm{kg}$, p.o., showed strong gastro- protective activity in mice; relieves gastrointestinal spasm and improves digestion. The plant extract was tested for adaptogenic activity showed anti-stress activity. The plant extracts showed positive inotropic property (cardio tonic effect); significantly prolonged the bleeding time. Administration at the dose of $1 \mathrm{~g} / \mathrm{kg}$ b.w. daily, for 15 days (in which serum biochemical changes were quantified) revealed no change in hematological parameters as compared to control.

The plant extract did not cause serious abnormal symptoms or death to animals in acute toxicity (the $\mathrm{LD}_{50}>10 \mathrm{~g} / \mathrm{kg}$, p.o.). The plant extract was tested for repeated dose toxicity and showed no noticeable toxic signs and symptoms in the treated animals at the dose of $2 \mathrm{~g} / \mathrm{kg}$, p.o. daily for 10 days. No significant change in vital organ weight (liver, spleen, kidney, uterus, ovaries, and testes) was recorded.

\section{References}

1. Jongbloed M V D, Feulner G R, Boer B, Western A R (2003) The comprehensive guide to the wildflowers of the United Arab Emirates. Abu Dhabi, UAE.

2. Fawzi M (1995) Weeds in the United Arab Emirates. Abu Dhabi, UAE, Flora of Pakistan.

3. Mandaville J (1990) Flora of eastern Saudi Arabia. London, UK: Kegan Paul International Ltd.

4. El Ghonemy A A (1993) Encyclopedia of medicinal plants of the United Arab Emirates. (1 $1^{\text {st }}$ edn.), Abu Dhabi, UAE.

5. Western A R (1989) The flora of the United Arab Emirates, an introduction. Abu Dhabi, UAE.

6. Usman G K, Nazir M (1982) Chemical constituents of Aerva javanica. Fitoterapia 3: 75-77.

7. Radwan H M, Nazif N M, Hamdy A A (1999) The lipid and flavonoidal constituents of Aerva javanica (var. bovi) Webb in Hook. F. and their antimicrobial activity. Egypt J Pharm Sci 40(2): 167-178.

8. Emam S S (1999) Phytochemical studies on the herb Aerva javanica growing in Egypt. Cairo University Faculty of Agriculture Bulletin 50: 488-514.

9. Saleh N A M, Mansour R M A, Markham K R (1999) An acylated isorhamnetin glycoside from Aerva javanica. Phytochemistry 29(4): 1344-1345. 


\section{Current Research in Diabetes \& Obesity Journal}

10. Wassel G M, Ammar N M (1987) Phytochemical study of Aerva lanata. Fitoterapia 58(5): 367.

11. Buckingham J (1995) Dictionary of natural products, Chapman \& Hall/ CRC, England.

12. Rastogi R P, Mehrotra B N (1993) Compendium of Indian medicinal plants, India p. 18.

13. Rastogi R P, Mehrotra B N (1991) Compendium of Indian medicinal plants, India p. 18.

14. Rastogi R P, Mehrotra B N (1998) Compendium of Indian medicinal plants. India p. 19.

15. Ahmed E, Imran M, Malik A, Ashraf M (2006) Antioxidant activity with flavonoidal constituents from Aerva persica. Arch Pharm Res 29(5): 343-347.

16. Imran M, Ibrahim M, Malik A (2009) Structure determination of aervins a-d, new coumarono chromone analogues from Aerva persica, by $1 \mathrm{~d}$ and $2 \mathrm{~d}$ nmr spectroscopy. Magn Reson Chem 47(6): 532-536.

17. Quality control methods for medicinal plant materials (1998) World Health Organization, Geneva, Switzerland.

18. Evans W C (1996) Trease and Evans' pharmacognosy (14 $4^{\text {th }}$ edn.), Saunders, London pp.105.

19. Wagner H, Bladt S (1996) Plant drug analysis: a thin layer chromatography atlas. $\left(2^{\text {nd }}\right.$ edn.), Springer-Verlag, Berlin, Heidelberg, pp. 384.

20. Srinivas K R (2009) Antihyperglycaemic activity of ethanol extract of Aerva javanica leaves in alloxan- induced diabetic mice. J Pharm Res 7.

21. Reddy S K, Srisailam K, Reddy V M (2009) Analgesic and antiinflammatory activity of various extracts of leaves of Aerva javanica. Adv Pharm Toxic 2: 11-17.

This work is licensed under Creative Commons Attribution 4.0 Licen

DOI: 10.19080/CRDOJ.2021.14.555890
22. Srinivas K R, Reddy V M (2009) Pharmacological evaluation of methanol extract of Aerva Javanica leaves for Central Nervous System depressant activity. Pharmacist 1 .

23. Khare C P (2007) Indian medicinal plants: an illustrated dictionary. Springer, USA

24. Rahmatullah Q, Bhatti G R (2009) Folklore uses of Amaranthaceae family from Nara Desert, Pakistan. Pak J Bot 4: 1565-1572.

25. Rashed M N (1995) Trace elements in some wild plants from the shores of the high dam lake and the adjacent desert, as determined by atomic absorption spectroscopy. J Ari Environ 2: 185-197.

26. Derelanko M J, Hollinger M A (2002) Handbook of toxicology ( $2^{\text {nd }}$ edn.), CRC Press, Boca Raton, USA, pp. 1440.

27. Han J, Hoosier G L V J (2003) Handbook of laboratory science, animal models. ( $2^{\text {nd }}$ edn.), CRC Press, USA.

28. British Herbal Pharmacopoeia (1996) (4 $4^{\text {th }}$ edn.), British Herbal Medicine Association (BHMA), UK, pp. 212.

29. Bauer A W, Kirby W M, Sherris J C, Turck M (1966) Antibiotic susceptibility testing by a standardized single disk method. Am J Clin Pathol 45: 493-496.

30. Mothana R A A, Abdo S A A, Hasson S, Althawab F M N, Alaghbari S A $\mathrm{Z}$, et al. (2008) Antimicrobial, antioxidant and cytotoxic activities and phytochemical screening of some Yemeni medicinal plants. Evid Based Complement Alternat Med 7(3): 323-330.

31. AOAC (1999) Official methods of analysis of AOAC International In: Kenneth Helrich $\left(15^{\text {th }}\right.$ edn.), Volume 1 \& 2.

Your next submission with Juniper Publishers
will reach you the below assets
- Quality Editorial service
- Swift Peer Review
- Reprints availability
- E-prints Service
- Manuscript Podcast for convenient understanding
- Global attainment for your research
( Panuscript accessibility in different formats
- Unceasing customer service
Track the below URL for one-step submission
https://juniperpublishers.com/online-submission.php

